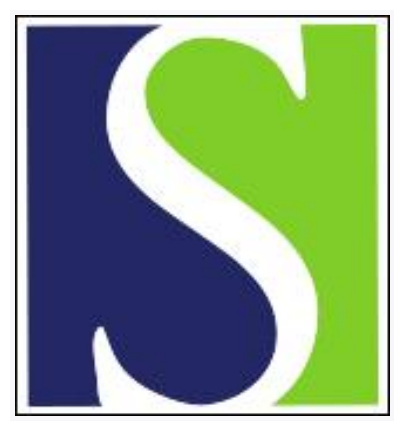

Scand J Work Environ Health 1978;4(3):246-254

https://doi.org/10.5271/sjweh.2701

Issue date: Sep 1978

A decrease in the prevalence and severity of vibration-induced white fingers among lumberjacks in Finland. by Pyykkö I, Sairanen E, Korhonen O, Farkkila M, Hyvärinen J

Key terms: chain saw; Finland; lumberjack; vibration disease; vibration-induced white finger

This article in PubMed: www.ncbi.nlm.nih.gov/pubmed/705291

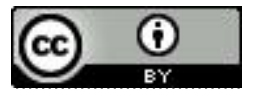




\title{
A decrease in the prevalence and severity of vibration-induced white fingers among lumberjacks in Finland
}

\author{
by ILMARI PYYKKÖ, M.D., ${ }^{1}$ EERO SAIRANEN, M.D., ${ }^{2}$ OLLI KORHONEN, M.D., ${ }^{3}$ \\ MARKUS FÄRKKILÄ, M.D., ${ }^{4}$ and JUHANI HYVÄRINEN, M.D. ${ }^{4}$
}

\begin{abstract}
PYYKKÖ, I., SAIRANEN, E., KORHONEN, O., FÄRKKILÄ, M. and HYVÄRINEN, $J$. A decrease in the prevalence and severity of vibration-induced white fingers among lumberjacks in Finland. Scand. j. work environ. \& health 4 (1978) 246-254. One hundred and eighty-seven lumberjacks in eastern Finland and 582 lumberjacks (in two groups of 501 and 81) in different parts of Finland were studied. In the first part of the study with 187 lumberjacks the prevalence of vibration-induced white fingers (VWF) was decreased from $40 \%$ in 1972 to $25 \%$ in 1975 . Retrospectively, the attacks of VWF became more common after 1965, the number of attacks being highest in 1970-1972. The severity of VWF among men who still had attacks was reduced in 1975 in comparison to 1972. The latent period of VWF was about 5,500 chain saw operating hours, which corresponds to five years of operating time, both in 1972 and in 1975. In the second part of the study $40 \%$ of 501 lumberjacks had had symptoms indicating VWF during the last two years. The severity of VWF was reduced in half of the subjects with VWF, but the reduction was not as marked as in the first part of the study. Numbness of hands and arms was present in more than half of the subjects in both phases of the study. No evident relief of this symptom had occurred during the follow-up period. The most probable reason for the decrease in the prevalence of VWF appeared to be the vibration damping of chain saws introduced in 1969. In part two of the study 81 lumberjacks had used only antivibration saws. The prevalence of VWF among them was $16 \%$ after an exposure time which equaled the mean latent period of VWF.
\end{abstract}

Key words: chain saws, lumberjacks, vibration disease.

Chain saw vibration gives rise to a variety of symptoms so severe that a worker sometimes has to give up his occupation. The most prominent of these are periodic

1 Department of Otolaryngology, University Central Hospital, Helsinki, Finland.

2 Enso-Gutzeit, Ltd., Helsinki, Finland.

3 Institute of Occupational Health, Helsinki, Finland.

4 Institute of Physiology, University of Helsinki, Helsinki, Finland.

Reprint requests to: Dr. O. Korhonen, Institute of Occupational Health, Haartmaninkatu 1, SF-00290 Helsinki 29, Finland. ischemic attacks provoked in fingers by cold weather, so-called traumatic vasospastic disease (TVD) (6), or vibration-induced white fingers (VWF) (19). Symptoms have also been reported in peripheral nerves $(13,24)$ and in muscles $(4,29)$ of hands and arms. These symptoms are included in the disease entity known as the vibration syndrome. Symptoms may occur simultaneously or separately. There is still some doubt, according to some investigators, about whether muscle weakness (8) and bone degeneration $(9,11,15)$ develop as a result of the vibration or the heavy and strenuous work of lumbering. 
Finland has a large lumbering industry with about 30,000 professional lumberjacks (7) who have been operating chain saws since the 1950s (2). The chain saws of the first generation were, however, heavy and clumsy and their use was limited.

In the early 1960s, when the second generation of chain saws became common, evidence from the National Board of Forestry indicated an alarming increase in the number of men with vasospastic symptoms. The prevalence of VWF among the lumberjacks rose in the late $1960 \mathrm{~s}$ and early $1970 \mathrm{~s}$ to $40-60 \%(14,21)$. These numbers were on the same level as the VWF prevalence of about $50 \%$ found in Scandinavia, Australia and England $(5,8$, $16,26)$.

The technical changes in the engines and the introduction of vibration damping devices have, since 1969 , reduced the acceleration on the handles of chain saws from $130-350 \mathrm{~m} / \mathrm{s}^{2}$ to $15-30 \mathrm{~m} / \mathrm{s}^{2}$ (27). Preliminary reports from Finland (23), England (28) and Sweden (30) indicate that the use of these third-generation chain saws [so-called antivibration (AV) chain sawsl has probably caused a decrease in the severity and prevalence of vibration syndrome.

We conducted a longitudinal study, as well as a supplementary one, to determine the present situation with respect to vibration syndrome among Finnish lumberjacks.

\section{LONGITUDINAL STUDY}

\section{Subjects and methods}

Investigations were made during the winters of 1972 and 1975. They were carried out in connection with a compulsory medical check-up of all the forest workers, 148 in 1972 and 250 in 1975, employed in Suomussalmi, situated in the northeast part of Finland, by the National Board of Forestry (21). Only men who had used a chain saw for at least three consecutive years with a minimum of $500 \mathrm{~h}$ per year, 118 in 1972 and 187 in 1975, were included in the study. During the follow- up period 23 of the 118 lumberjacks under study in 1972 resigned or retired. Ninetyfive lumberjacks from the group investigated in 1972 were included in the group under study in 1975. A questionnaire was sent to those who had quit to find out the reason for their resignation, and the diagnoses of retired men were checked from the Social Insurance Institution. The age distribution is given in table 1.

In 1972 and 1975 the following procedures were carried out. Lumberjacks completed a questionnaire in advance on their state of health, symptoms of vibration syndrome and smoking habits. A medical history was recorded, and a physical examination was carried out. Symptoms and signs indicating VWF were registered on both occasions by the same physician. All lumberjacks with a history of white fingers were given a cold provocation test (22).

The diagnosis of VWF was made according to a typical history of blanching of fingers. Other causes were ruled out with the aid of the history, the clinical examination, and routine laboratory tests. If more than two years had elapsed since the last attack of VWF, the lumberjack was no longer classified as disabled.

The severity of VWF was evaluated with the aid of a TVD index (21). The factors included in the index are shown in table 2. The individual factors were scaled with numerical values from 0 to 2 ; separate scale values were added for the index.

In 1975 the lumberjacks gave a subjective evaluation of their occupational disability due to different symptoms of VWF and back disorders in their medical history.

Table 1. Age distribution of the lumberjacks in the longitudinal study.

\begin{tabular}{rrrrrr}
\hline \multirow{2}{*}{$\begin{array}{l}\text { Age } \\
\text { (years) }\end{array}$} & \multicolumn{2}{c}{1972} & & \multicolumn{2}{c}{1975} \\
\cline { 2 - 3 } \cline { 5 - 6 } & $\mathrm{N}$ & $\% \%$ & & $\mathrm{~N}$ & $\%$ \\
\hline & & & & & \\
$\leq 29$ & 32 & 27 & & 45 & 24 \\
$30-39$ & 48 & 41 & & 57 & 30 \\
$40-49$ & 34 & 29 & & 76 & 41 \\
$\geq 50$ & 4 & 3 & & 9 & 5 \\
\hline Total & 118 & 100 & & 187 & 100 \\
\hline
\end{tabular}


Table 2. Variables included in the traumatic vasospastic disease index for evaluating the degree of severity of vibration-induced white fingers.

\begin{tabular}{|c|c|c|c|}
\hline \multirow{2}{*}{ Variable } & \multicolumn{3}{|c|}{ Scale value } \\
\hline & 0 & 1 & 2 \\
\hline Number of phalanges & & & \\
\hline affected & $1-4$ & $5-14$ & 15 or more \\
\hline Recovery time in forest & $\begin{array}{l}\text { less than } \\
5 \mathrm{~min}\end{array}$ & $\begin{array}{l}5-15 \\
\min \end{array}$ & $\begin{array}{l}\text { more than } \\
15 \text { min }\end{array}$ \\
\hline $\begin{array}{l}\text { Result of cold provo- } \\
\text { cation test }\end{array}$ & negative & $\begin{array}{l}\text { one hand } \\
\text { positive }\end{array}$ & $\begin{array}{l}\text { both hands } \\
\text { positive }\end{array}$ \\
\hline $\begin{array}{l}\text { Number of attacks } \\
\text { per week }\end{array}$ & less than 1 & $1-4$ & 5 or more \\
\hline $\begin{array}{l}\text { Warmest weather likely } \\
\text { to provoke attacks }\end{array}$ & severe cold & damp cold & $\begin{array}{l}\text { cool summer } \\
\text { weather }\end{array}$ \\
\hline
\end{tabular}

\section{Results}

The prevalence of VWF in 1972 and 1975 is given in fig. 1. The course of VWF in different years was estimated retrospectively (fig. 2). After 1965 attacks of VWF

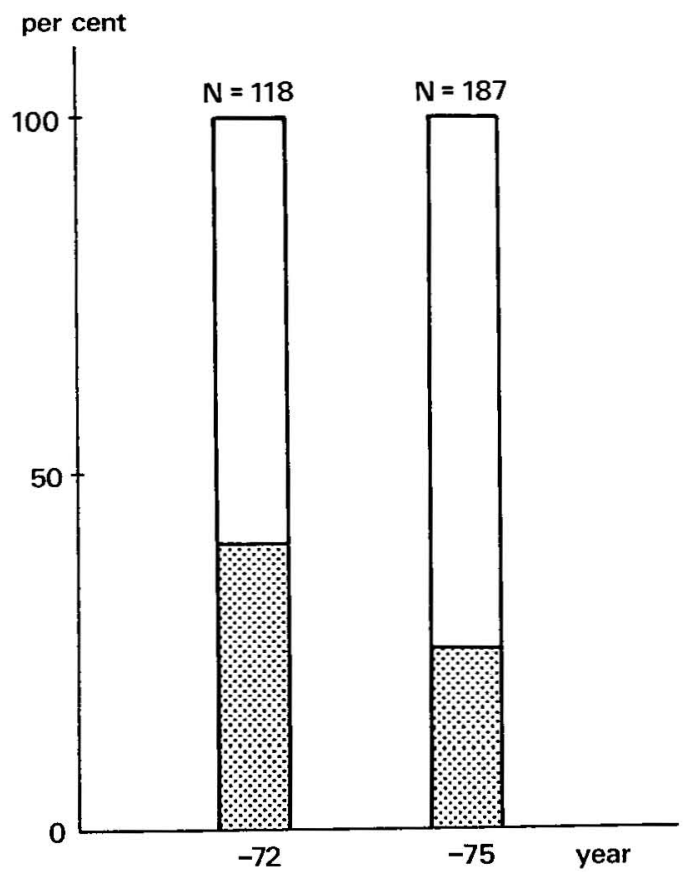

Fig. 1. Prevalence of vibration-induced white fingers in 1972 and 1975 among lumberjacks of Suomussalmi, Finland, in the longitudinal study. started to become more common, the number of attacks among these 187 men being highest in the years 1970-1972. After 1972 only three new lumberjacks were disabled by VWF. They had also used the older types of chain saws.

Latent interval. The mean total time for operating a chain saw before 1972 was 11 years (range $3-20$ years) and before 1975 also 11 years (range $3-21$ years). The time was counted also in hours to get the mean latent period of VWF. In 1972 the latent interval was $5,600 \mathrm{~h}$ (SD 2,500 h), which was essentially the same as the $5,400 \mathrm{~h}$ (SD 2,600 h) recorded in 1975 (fig. 3). Expressed in years the mean latent period was $4-5$ years.

Severity of vibration-induced white fingers. Fig. 4 shows the changes that occurred in the TVD index of those 26 lumberjacks who had symptoms indicating TVD both in 1972 and 1975. The TVD index, describing the degree of severity of VWF, had decreased in all except two lumberjacks.

Numbness of hands and arms. In 1972, $78 \%$ of the 118 lumberjacks suffered from numbness of the hands and/or arms. A slight decrease in the prevalence of this symptom was observed in 1975, when $53 \%$ of the 187 lumberjacks reported having numbed hands and/or arms. This symptom was present mainly during the night and morning. In some cases it woke 


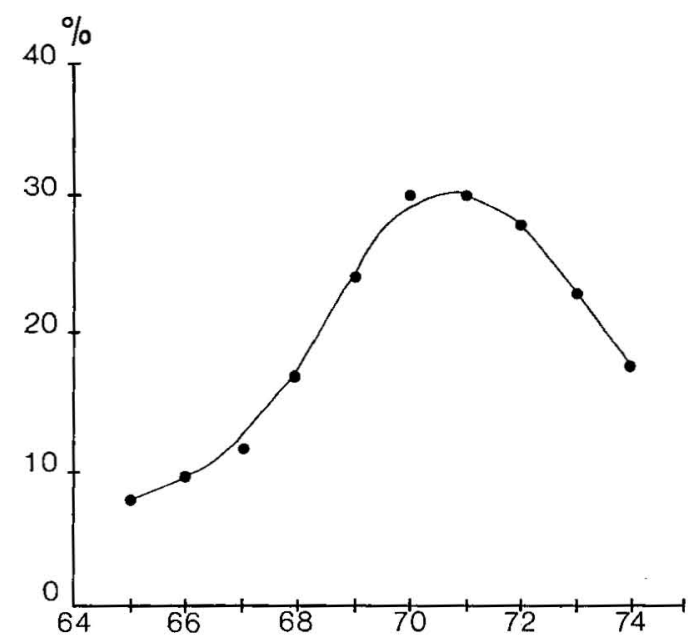

Fig. 2. The prevalence $(\%)$ of attacks of vibration-induced white fingers among Finnish lumberjacks between 1965-1974 in the longitudinal study. The number of lumberjacks was 137 in 1965 and increased almost linearly to 187 in 1975.

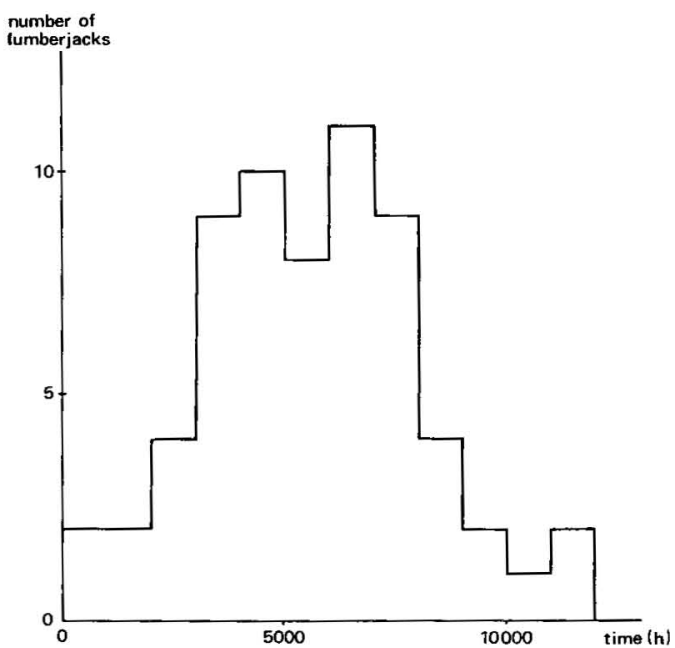

Fig. 3. Latent period of the vibration-induced white fingers found in 64 of the 187 lumberjacks in the longitudinal study.

the lumberjack and forced him to massage his hands and arms two or three times every night.

Occupational disability. Three of the 118 lumberjacks under study in 1972 left this work because of VWF. The subjective evaluation of the occupational disability due to some symptoms of the vibration syndrome in 1975 is given in table 3 . The annoyance caused by blanching fingers was generally considered mild; only three lumberjacks reported a severe occupational disability. Numbness of the hands and arms was reported to cause considerable occupational disability by 21 lumberjacks, and 9 of these considered the symptom severe enough to reduce their wages.

The subjective evaluation of occupational disability caused by a stiff and/or painful back as well as pain in the upper extremities is given in table 4 .

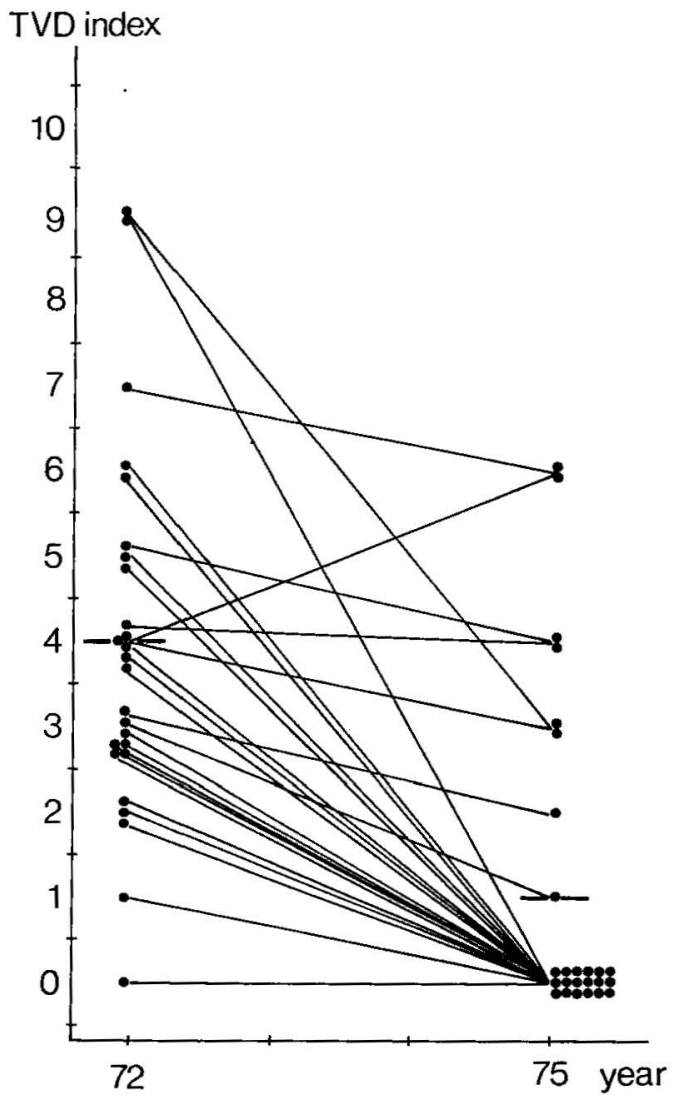

Fig. 4. The severity of vibration-induced white fingers, expressed as traumatic vasospastic disease (TVD) index, in 1972 and 1975. Mean values of the indices have been drawn with thicker lines. 
Table 3. Subjective evaluation of the occupational disability of the 187 lumberjacks in the longitudinal study in 1975 due to some symptoms of vibration syndrome.

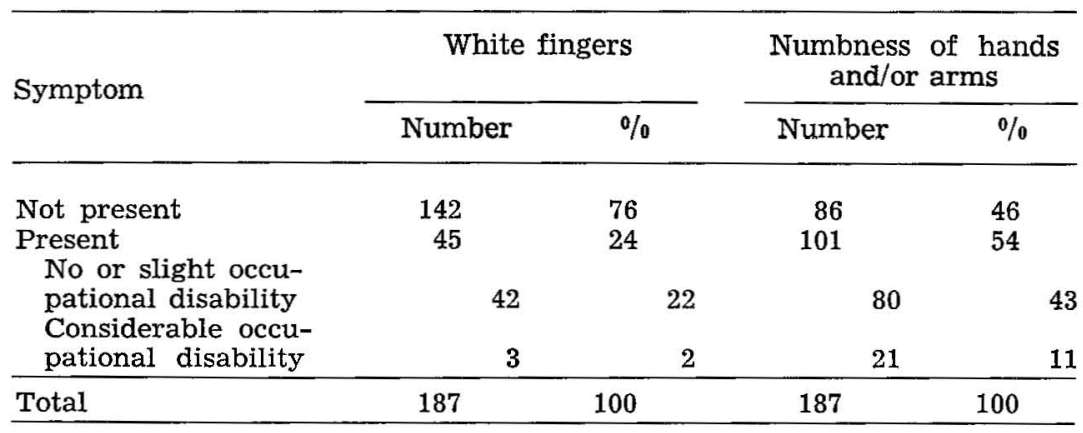

Table 4. Subjective evaluation of the occupational disability of the 187 lumberjacks in the longitudinal study in 1975 due to symptoms of back and upper extremities.

\begin{tabular}{|c|c|c|c|c|c|}
\hline \multirow{2}{*}{ Symptom } & \multicolumn{2}{|c|}{$\begin{array}{l}\text { Pain and } / \text { or } \\
\text { stiffness in back }\end{array}$} & \multicolumn{3}{|c|}{$\begin{array}{l}\text { Pain in upper } \\
\text { extremities }\end{array}$} \\
\hline & Number & $\%$ & Number & $\%$ & \\
\hline Not present & 59 & 32 & 95 & 51 & \\
\hline Present & 128 & 68 & 92 & 49 & \\
\hline $\begin{array}{l}\text { No or slight } \\
\text { occupational disability } \\
\text { Considerable }\end{array}$ & 87 & 46 & 73 & & 39 \\
\hline occupational disability & 41 & 22 & 19 & & 10 \\
\hline Total & 187 & 100 & 187 & 100 & \\
\hline
\end{tabular}

\section{SUPPLEMENTARY STUDY}

\section{Subjects and methods}

The supplementary study was conducted in 1975 in different parts of Finland and comprised two different groups of professional lumberjacks working for one lumbering company.

Group 1 consisted of 501 lumberjacks who had used a chain saw for at least four years with a minimum of $1,000 \mathrm{~h} /$ year. The age distribution of group 1 is shown in table 5.

Group 2 consisted of 81 men who had started lumbering in 1970 and had used only the AV type of chain saws. The age distribution of this group is shown in table 6 .
The data were collected from questionnaires and a compulsory medical checkup. In the questionnaires and during the interviews made to obtain the medical history, symptoms of vibration syndrome and their changes within the past two years were inquired about, as well as subjective disability due to VWF. Other causes than vibration were excluded.

\section{Results}

Group 1. The mean chain saw operation time was 10 years (range $4-18$ years). Out of a total of 501 lumberjacks, $201(40 \%)$ had had symptoms indicating VWF at some stage. Numbness of hands and/or arms was present in $288(58 \%)$ lumberjacks. The subjective evaluation of changes in these 
symptoms is given in table 7. The white finger symptom decreased during 19731975 in the majority of those who suffered from it, whereas the numbness symptom showed the opposite tendency. The difference between the changes in the two symptoms was highly significant $\left(\chi_{[1]}^{2}=\right.$ $56.69, \mathrm{p}<0.001$ ).

On the self-administered questionnaires 51 men $(10 \%)$ considered themselves to have considerable occupational disability because of VWF, whereas only $7(1 \%)$ reported the same during the physician's interview.

Group 2. Of the 81 lumberjacks, $13(16 \%)$ had a typical history of VWF. Numbness of hands and/or arms was present in 23 $(28 \%)$ of these lumberjacks.

\section{DISCUSSION}

The prevalence of VWF had decreased during the follow-up period. The number of new cases was highest in 1967-1969, and the highest prevalence was reached in 1971. The TVD index indicated that in most men who still had attacks of VWF a decrease in severity had occurred. An improvement was observed both in the reduced frequency of attacks and in a shortened recovery time.

Stewart and Goda (25) observed that five years after the cessation of work $30 \%$ of the workers no longer experienced attacks of VWF. We sometimes found a positive cold provocation test in men who had not had a single attack of VWF for five years. It is therefore debatable whether those regarded as recovered have really improved or whether they, under some unfavorable conditions, could still suffer from VWF. Agate (1) reported that in some workers attacks of VWF were first seen some months after they left their job with vibrating instruments. In workers already having VWF, vascular disturbances showed a tendency to progress. rather than to disappear after the cessation of work.
Table 5. Age distribution of the 501 lumberjacks in group 1 of the supplementary study.

\begin{tabular}{lrr}
\hline $\begin{array}{l}\text { Age } \\
\text { (years) }\end{array}$ & $\mathrm{N}$ & $\%$ \\
\hline & & \\
$\leq 29$ & 161 & 32 \\
$30-39$ & 135 & 27 \\
$40-49$ & 140 & 28 \\
$\geq 50$ & 65 & 13 \\
\hline Total & 501 & 100 \\
\hline
\end{tabular}

Table 6. Age distribution of the 81 lumberjacks in group 2 of the supplementary study.

\begin{tabular}{lrr}
\hline $\begin{array}{l}\text { Age } \\
\text { (years) }\end{array}$ & $\mathrm{N}$ & $\%$ \\
\hline$\leq 29$ & 68 & 84 \\
$30-39$ & 9 & 11 \\
$40-49$ & 4 & 5 \\
$\geq 50$ & 0 & 0 \\
\hline Total & 81 & 100 \\
\hline
\end{tabular}

Table 7. The subjective changes that occurred in the stage of vibrationinduced white fingers and numbness of the hands and/or arms in 19731975 among the 501 lumberjacks in the supplementary study.

\begin{tabular}{|c|c|c|c|c|}
\hline \multirow{2}{*}{ Symptom } & \multicolumn{2}{|c|}{ White fingers } & \multicolumn{2}{|c|}{$\begin{array}{c}\text { Numbness of hands } \\
\text { and/or arms }\end{array}$} \\
\hline & Number & $\%$ & Number & $\%$ \\
\hline $\begin{array}{l}\text { Not present } \\
\text { Present }\end{array}$ & 300 & 60 & 213 & 43 \\
\hline $\begin{array}{l}\text { Present } \\
\text { Decreased }\end{array}$ & ${ }^{201} 111$ & $\begin{array}{ll}40 & 22\end{array}$ & 30 & 6 \\
\hline Same & 70 & 14 & 202 & 40 \\
\hline Deteriorated & 20 . & 4 & 56 & 11 \\
\hline Total & 501 & 100 & 501 & 100 \\
\hline
\end{tabular}


Among chain saw operating lumberjacks in Sweden, a six-year follow-up showed that the prevalence of VWF had decreased from 48 to $38 \%(30)$. In England, Taylor (28) annually estimated, with the aid of an index, the severity of VWF among 54 chain saw operating lumberjacks. A significant relief in VWF had taken place during the last two years. Therefore it seems that recovery from VWF is possible. However, it is likely that a prolonged period is required before the abnormal reactivity of the peripheral vessels subsides $(10,17)$ and the structural changes of the vessel walls regress $(3,6,25)$.

The reversibility of VWF in established cases and a low prevalence of VWF in new cases do not result from a single factor only. Most important seems to be the significant reduction in the vibration level of the chain saws manufactured since 1969. In these AV chain saws the acceleration level of vibration was decreased by about $20 \mathrm{~dB}$ (27). A $20 \mathrm{~dB}$ decrease in daily vibration exposure means, according to different norms, an increase in the maximal allowed daily operation time from 0.5 to $8 \mathrm{~h}(18,20)$. The importance of the reduction of vibration is supported by the finding that during the use of the AV chain saws only three men in our longitudinal study had been disabled. They had all also used the older types of chain saws.

In our supplementary study the prevalence of VWF was $16 \%$ among men who had used solely the AV type of chain saws. However, the follow-up period was too short to come to final conclusions about the prevalence of VWF caused by these saws. These men have not been working for more than five years, which is the mean latency period of VWF. Therefore the final prevalence may well be more than $16 \%$.

Traveling to and from work in open vehicles during cold seasons was common earlier and often provoked attacks of VWF. Closed transportation, which is customary nowadays, probably caused an improvement in some lumberjacks (21). Another reason for the recovery might be the warm winters in the years 1971-1974. In many individuals, however, attacks of VWF are provoked most often during moist, about $0^{\circ} \mathrm{C}$, weather (21). This kind of weather was very common during these winters, and therefore this factor probably did not play a significant role in the decrease that occurred in the prevalence of VWF.

The noise level of chain saws [103-107 $\mathrm{dB}(\mathrm{A})$ ] exceeds the level above which peripheral vasoconstriction starts to occur [75 dB (A)]. A positive correlation has been shown to exist between a noisy environment and Raynaud's phenomenon (12). In 1972 about $80 \%$ of the lumberjacks used ear muffs, whereas more than $95 \%$ used them in 1975, a factor which possibly prevented the appearance of vasoconstriction in VWF. In spite of the lumberjacks' increasing knowledge of the fact that smoking is one factor which provokes VWF (21), the amount of smoking did not decrease during the follow-up period. Hence the reduction of VWF cannot be connected with a change in smoking habits.

Shooting pains and numbness of the hands and arms are common in lumberjacks and only minor relief of these symptoms was observed. The symptoms were present in more than half of the subjects studied. Numbness of the hands and arms is, however, common also in workers who have only a minimal exposure to vibration (25). This symptom could partly be a result of the strenuous work of lumbering or over-stressed musculature. On the other hand, it is known that injuries in nerve tissue heal unsatisfactorily and require a long time to heal (25). It is possible that AV chain saws do not cause nervous symptoms as often as the older saws. The prevalence of numbing of hands was $28 \%$ among those men who had used solely the AV chain saws, but their exposure time was possibly too short for final conclusions.

Klimkovà-Deutschová (13) reported severe numbness of hands and arms in $60 \%$ of the workers using vibrating tools. This symptom was considered subjectively to be a cause of handicap also in the lumberjacks of Suomussalmi, but to a lesser degree. Eleven per cent of them considered their symptoms to be severe, and some of these rated their symptoms as severe enough to cause a reduction in wages.

When the severity of signs and symptoms of the vibration syndrome is compared with the severity of symptoms 
caused by overloading joints, particularly the lower lumbar vertebrae, the latter, including lower back pain, seems to dominate in Finnish lumberjacks.

Improvements have occurred during the last five years in the process of lumbering, e.g., the new AV chain saw, car transportation and the use of ear muffs. The severity of symptoms and the prevalence of VWF have both decreased during the last five years. On the other hand, approximately half of the lumberjacks suffer from numbness of hands and arms, especially during sleep, and no relief in these symptoms was found during the follow-up period.

\section{CONCLUSIONS}

1. The prevalence and severity of one symptom and sign of vibration syndrome, blanching of fingers, has decreased in Finland in recent years. The most probable reasons are vibration damping of chain saws and warm car transportation.

2. The prevalence and severity of numbness of hands and/or arms, which may be a symptom of vibration syndrome, has not decreased in recent years. Therefore, it is still too early to make final conclusions on the prevalence of the whole vibration syndrome.

\section{REFERENCES}

1. AGATE, J. N. An outbreak of cases of Raynaud's phenomenon of occupational origin. Br. j. ind. med. 6 (1949) 144-163.

2. AHO, K. Method of measuring the vibration of chain saws and evaluating the results (Vakola study report no. 8) Vakola, Helsinki 1971, pp. 1-19.

3. ASHE, W. F., COOK, W. T. and OLD, J. W. Raynaud's phenomenon of occupational origin. Arch. environ. health 5 (1962) 333343.

4. BANISTER, P. A. and SMITH, F. W. Vibration induced white fingers and manipulative dexterity. $\mathrm{Br}$. j. ind. med. 29 (1972) $264-267$.
5. BARNES, R., LONGLEY, E. O., SMITH, A. R. B. and ALLEN, J. G. Vibration disease. Med. j. aust. 1 (1969) 901-905.

6. GURDJIAN, E. S. and WALKER, L. W. Traumatic vasospastic disease of the hand (white fingers). J. am. med. assoc. 129 (1945) $668-672$.

7. HEIKINHEIMO, L., HEIKINHEIMO, M., LEHTINEN, M. and REUNALA, A. Suomalainen metsätyömies. Werner Söderström Osakeyhtiö, Porvoo 1972, pp. 9-20.

8. HELLSTRØM, B. and LANGE ANDERSEN, $\mathrm{K}$. Vibration injuries in Norwegian forest workers. Br. j. ind. med. 29 (1972) 255-263.

9. HORVÂTH, F., KÁKOSY, T. and VILLÁNYI, G. Structural changes of the carpal bones in motor saw workers. Magy. radiol. 21 (1969) 257-266. (English abstract)

10. HYVÄRINEN, J., PYYKKÖ, I. and SUNDBERG, S. Vibration in frequencies and amplitudes in the aetiology of traumatic vasospastic disease. Lancet 1 (1973) 791794.

11. JAMES, P. B., YATES, J. R. and PEARSON, J. C. G. An investigation of the prevalence of bone cysts in hands exposed to vibration. In: W. TAYLOR and P. L. PELMEAR (eds.), Vibration white finger in industry. Academic Press Inc., London 1975 , pp. $43-51$.

12. JANSEN, G. Zur Entstehung vegetativer Funktionstörungen durch Lärmeinvirkung. Arch Gewerbepath. Gewerbehyg. 17 (1959) 238-261.

13. KLIMKOVA-DEUTCHOVA, E. Neurologische Aspekte der Vibrationskrankheit. Arch. Gewerbepath. Gewerbehyg. 22 (1966) $297-305$.

14. KUMLIN, T. Tärinäsairaus. Duodecim 89 (1973) $11-18$.

15. KUMLIN, T., WIIKERI, M. and SUMARI, P. Radiological changes in carpal and metacarpal bones and phalanges caused by saw vibration. Br. j. ind. med. 30 (1973) $71-73$.

16. KYLIN, B. and LIDSTRÖM, I.-M. Hälsooch miljöundersökning bland skogsarbetare (AI-raport no. 5). Arbetsmedicinska Institutet, Stockholm 1968 pp. 44-62.

17. LEWIS, T. Vascular disorders of the limbs (2nd ed.). MacMillan, London 1949. $118 \mathrm{p}$.

18. LOUDA, L. The Czechoslovakian hygiene regulation on protection against vibration (1967). Cited in: KRYŽE, B. The Czechoslovakian hygiene regulation on protection against vibration. Work environ. health 7 (1970) $51-65$.

19. MC CALLUM, R. I. Vibration syndrome. Br. j. ind. med. 28 (1971) 90-99.

20. MINISTERSTVO ZDRAVOOHRANENIJA. Sanitarnie normi i pravila. Moscow, 1966. $39 \mathrm{p}$.

21. PYYKKठ, I. The prevalence and symptoms of traumatic vasospastic disease among lumberjacks in Finland. Work environ. health 11 (1974) 118-131.

22. PYYKKÖ, I. Vibration syndrome: A review. In: O. KORHONEN (ed.), Vibration and work. Institute of Occupational Health, Helsinki 1976, pp. 1-24. 
23. SAIRANEN, E. Terveydenhuoltotyö metsäosastolla. Ehkäise tapaturmia (1973): 4-5, 8-9.

24. SEPPÄLÄINEN, A. M. Peripheral neuropathy in forest workers: A field study. Work environ. health 9 (1972) 160-111.

25. STEWART, A. M. and GODA, D. F. Vibration syndrome. $B r . j$. ind. med. 27 (1970) $19-27$.

26. TAYLOR, W. T., PEARSON, R. L. and KEIGHLEY, G. D. Vibration syndrome in foresty commission chain saw operators. Br. j. ind. med. 28 (1971) 83-89.

27. TAYLOR, W., PELMEAR, P. L., HEMPSTOCK, T. I., O'CONNOR, D. E. and KITCHENER, R. Correlation of epidemio- logical data and the measured vibration. In: W. TAYLOR and P. L. PELMEAR (eds.), Vibration white finger in industry. Academic Press, Inc., London 1975, pp. $123-133$.

28. TAYLOR, W., PELMEAR, P. L. and PEARSON, J. C. G. A longitudinal study of Raynaud's phenomenon in chain saw operators. In: W. TAYLOR and P. L. PELMEAR (eds.), Vibration white finger in industry. Academic Press, Inc., London 1975, pp. 15-20.

29. TELEKY, L. Pneumatic tools. Occup. health 1 (1938) $1-12$.

30. THULESIUS, O. Methods for the evaluation of peripheral vascular function in the upper extremities. Acta chir. scand. (1976) $53-54$.

Received for publication: 7 December 1977 